\title{
Chronicle of a Quest: Silence after Killing ${ }^{1}$
}

\section{Leshu Torchin}

Companion and complement to its predecessor, The Act of Killing (2013), Joshua Oppenheimer's new film The Look of Silence (2014) continues the explorations launched in the earlier work. Once again, Oppenheimer reflects on the genocidal murders that came in the wake of the failed Suharto coup of 1965-66 with attention to its resonance in the present, the ongoing impact of impunity, and the cinematic mediation of collective memory. Yet surprisingly, unlike the "flamboyant fever dream" of the first film, focused on former assassins and torturers producing an epic chronicle of past exploits, Silence returns testimony of the morst sober kind to the fore. $^{2}$ This time, Oppenheimer's attention is not on the murderers but on the survivors of the genocide, who live in a world designed and governed by the perpetrators of past violence.

Where Killing is grandiose and bombastic and full of delirious displays of cinema, Silence is intimate, and meditative, composed of rigorous observation and interviews. Such a transition reflects an anxiety regarding the representation of trauma. This anxiefyoften takes the form of an opposition between entertainment and art film, whereln the former delivers pleasure and the semblance of understanding while the latter refuses such a presentation, opting for a modernist, often fragmented, aesthetic that mirrors the effects of trauma on the psyche. ${ }^{3}$ In this case, Killing depicts the "enfablement" of atrocities, to use Hayden White's term, as its criminal protagonists purport to produce something comprehensive and comprehensible. ${ }^{4}$ Silence, however, focuses on the elusiveness of a past that paradoxically intrudes upon the present... 
Here, Oppenheimer, mostly offscreen, follows his protagonist, the optometrist Adi, as he visits the homes of former assassins, many ensconced in government and high-powered positions. Seeking confessions and expressions of contrition, Adi is often thwarted in his goal. As such, Silence refuses easy cinematic satisfaction, emotional if not epistephilic, even when providing the witnesses to the events. Trauma or the recitation of traumatic events is present yet elusive, as perpetrators manage to concede and deny the horrors, and victims are silenced through institutional threat, age, and dementia.

The chronicle of Adi's quest is depicted entirely through the documentary strategy of an observational camera with patient and tireless interviews that confer the expected authority to represent reality associated with the mode. While the mission evokes exposé, the style imposes stoicism, and ensures a commitment to uncovering a hidden truth. By contrast, Killing's lurid and spectacular fantasies defy the still lingering popular expectations of sobriety, particularly in response to genocide, as it unsettles documentary's evidentiary'status. Indeed, Film Quarterly's dossier on that film was replete with observations of its unsteady distinctions between truth and fiction. ${ }^{5}$ Silence, on the other hand, uses different methods entirely to ensure that the truth is on its side the side of the survivors - even as the film supplies those aesthetic disruptions familiar in traumatic narratives, in particular a sonic landscape whose cacophony of insects disturbs the otherwise still setting; in this case, it is the trauma of both history and historiography that reverberates.

Questions of ethics are as pressing as aesthetic choices in representations of a traumatic event. Killing's granting of a platform to perpetrators, who already control its recounted history, might seem indulgent at best, and at worst, as Nick Fraser charged, result in a "high-minded snuff movie." As such, it might appear to the 
casual observer as if Silence were produced entirely to quell these reservations-were it not for the fact that it had been shot before Killing was ever released or criticisms published.

But the backstory provides another narrative. When working on The Globalisation Tapes (2003), a collaboratively produce documentary billed as "by workers and for workers" about the struggle of union organizers on a palm oil plantation, Oppenheimer encountered the long shadow of the genocide in the anxiety of the workers he was filming. In 1965, union organizers had been targeted as "communist sympathizers" and imprisoned or murdered; an atmosphere of dread and fear of recurrence flourished in the present, as killers lived immune from due process. Oppenheimer has recounted how the survivors asked hîm, once this documentary was complete, to return to tell their story, not just of the violent purge but also of their current circumstances living among the murderers of their families and friends. ${ }^{7}$ The Globalisation Tapes, foregrounding the workers behind and in front of the camera through observation and interview, and intended for sharing with workers around the world, stands today as an indication of Oppenheimer's early interest in social justice and the voices of the people chronicled. ${ }^{8}$

Upon his return in 2003, when Oppenheimer began to collect the testimonies of the survivors, he heard, amidst them, a name repeated. Ramli, one of many massacred at Snake River, was an unusual victim because his case was so public and with so many witnesses that it became a "synonym for the killings in general."9 Following that discovery, he met with the family: Rohani (Ramli's mother), Rukun (his father), and his brother Adi, born after Ramli's death. At the same time, the community requested that Oppenheimer try to film the perpetrators, since as an outsider, he was likely to be safe from repercussions. This process led to the discovery 
of Ramli's actual murderers, Inong and Amir Hasan, and to his meeting the higherranking perpetrators who became the star subjects of The Act of Killing. Oppenheimer ended up shooting Killing first, then shot The Look of Silence prior to the first film's release.

Although it functions as a stand-alone piece, Oppenheimer's The Look of Silence forms a diptych together with The Act of Killing that calls up, reflects upon, and interrogates representations of genocide in cinema. Whereas Killing highlights the role of fantasy and reenactment, delivering a spectacle that recalls many of cinema's entertaining and epic historical re-creations, Silence performs an illustration and interrogation of the possibilities and limitations of filmed testimeny. Silence's focus is not purely grounded in questions of representation, for that is a direction that either spirals into a postmodern relativism or generates repeated debates over the possibilities of depicting trauma. Rather, itsattention turns to the practical necessity of collecting testimony and the challenges that arise in a context of combined denial and menace.

If testimony is the fruthful narration of a past occurrence for purposes of transformation and socia justice, how does it function in a site flooded by fantasy, amnesia, and intimidation? While its staid approach aligns the survivors and their experience with the truth and deploys its evidentiary value in possible preparation for testimony in a social justice project, the witness documentary is not free from the questions that attend documentary and testimony alike. Mnemonic, historiographic, perceptual, and epistemological challenges beset the act of witnessing, which includes bearing witness, its mediation, and its transformative aims. John Durham Peters refers to these challenges as a "veracity gap," a charged term that has its appeal, particularly 
in light of the sober mode that seeks to close this gap even as the documentary engages it. ${ }^{10}$

Silence follows optometrist Adi, born after the coup and conceived to replace his brother, Ramli, as he conducts eye exams and interviews in tandem, seeking answers and confessions from the murderers who live in the community, often holding positions in local government. An offscreen Oppenheimer, whose filming is equally invisible, accompanies Adi on his quest for the evidence and full story of his brother's murder. Once again, perpetrators are called upon to bear witneŝs, allowing questions of representation and mediation to return; but this time, theepic visions and lurid fictions of the earlier film are replaced by prodding face-to-face encounters. With this project, Oppenheimer changes gears from the macro to the micro, and turns attention to these smaller performances and mediations of the past. Intentionally or not, the shift of register enables the scrutin $x$ of filmed testimony while shoring up its evidentiary value. The practical possibilities of using testimony come into view, too, as the film's own accumulation of statements and observations creates an archive for future deployment in human rights efforts.

From the outset, Silence's still close-ups invite scrutiny of the natural world that conceals theatrocities of the past. An unidentified man wears a phoropter, an ophthalmic testing device that will appear throughout the film, and gazes into the camera. Twittering insects continue to provide the soundtrack to the image. Pods containing moth larvae are doubly haunted, their reflections visible in the table surface as they roll and twitch on their own.

The film cuts to a man (later identified as Adi) staring offscreen. On the soundtrack, a male voice sings a song asking why one should remember when memory causes nothing but pain. This is not simply a director's poetically suitable 
song selection, nor a ghostly sonic haunting of this one man's intimate close-up.

Rather, the song emanates from a television set, revealed in the next shot, playing the shameless testimony of Ali Suk, who recounts his killing of a man by strangling and then tearing out his intestines. He sits in his lounge, presumably at home, with a child seated not far from him. The relative stillness and quiet cannot hide the efflorescence of meaning: the political violence of the past saturates domestic space and crosses generations. Its noise is constant in the face of the silent victims, whose onscreen domestic space is in turn invaded by the presence of the television set from which the testimony issues forth.

In Silence, Oppenheimer seems finished with grand reenactments. The hallucinatory reveries of Killing's perpetrators have not been discarded, however, so much as muted and filtered, refracted and reinterpreted, into a constant presence in the everyday lives of Indonesians haunted by the past. Long takes of a landscape buzzing with crickets and insects supply a motif of constant occupation in a present infused by the violence of the past. The past meanwhile remains ever-present, both in its rewriting into triumphalist national narrative and in the real presence of former genocidaires in regional government. Even the film's most restrained and transparent expressions arestamped with impressions of past trauma and its reverberations in the present. These domestic and intimate images are well suited to the big screen, not only because they are stunning, but because they address the way this horrific past exceeds containment and occupies every aspect of Indonesian life, public and private.

The burdens of denial and past violence are manifested explicitly in an expository sequence set in a classroom where "denial" refers not to refutation of events but to their meaning, too, as Adi's son receives a lesson that transforms the perpetrators of the coup into national heroes and repositions their victims as threats. In 
contrast to Killing's fantasies of history, this scene's straightforward delivery

indicates the practical ways in which a national narrative inhabits the lived world. The class instructor details the matter-of-fact ways in which the children and grandchildren of communists are barred from participation in the civic sphere.

In the next scene, Adi and his son speak about the lesson in a wide shot that renders them entirely peripheral and almost invisible within the frame. Form enhances this story of exclusion: the bulk of the screen space is dedicated to a landscape, devoid of people but burdened with the structuring absence of the genocidal purge and the fabricated narrative that now dominates. Such still compositions deploy documentary style in an articulation of painful liminality. The film's observational stance, with its claim on transparency, can express the truth of their marginalization but cannot depict the past that imposes itself on their lives.

Questions of who can bear witness are fraught in such a context. It is evident from the credits of this film (and those of The Act of Killing), overwhelmed by the name "Anonymous," that a significant threat still exists in Indonesia. Oppenheimer's own inability to return to the nation as well as his disclosure of numerous contingency plans for flight set up during the production points to the risks inherent in testifying to the truth of themassacres. Upon the conclusion of filming, in fact, Adi Rukun and his family had to move to another part of Indonesia after receiving unwanted attention from former killers and even the military. ${ }^{11}$

Although institutional and state intimidation is often sufficient to enforce testimonial censorship, the physical and mental health of survivors and victims works to amplify this silence. The dead cannot testify and others, who have been thoroughly traumatized, may be in no state to contribute effectively to an historical record that requires clarity and sobriety. ${ }^{12}$ Trauma, as many of its scholars have noted, is not 
simply the direct result of a precipitating event, but equally includes its effects on that event's narration and psychic integration. ${ }^{13}$

With Silence, historical erasure moves from the official to the personal, and from the theoretical to the physical. Adi's father embodies the challenges: blind and aged, he suffers from a dementia that erodes whatever living memory remains. Under questioning, he identifies himself as a younger man, erasing years from his life. When his wife asks if he remembers his son, the response would be comical if not so heartbreaking, "Which son? Remember what? Whose son?" At another point in the film, he moves about in a terror as he drags his body across the floor, unable to recognize his surroundings or to recall his murdered son, yet nonetheless tormented by past horrors.

Although this elder gives a somatic testimony, his capacity to articulate his experience and what he has seen is tragicalty limited, as confined and fragile as the man himself. Adi's mother is able to provide all the details about the past that his father cannot, but even she cannot offer more than hearsay when it comes to her elder son's murder at Snake River.Her desire for a spiritual retribution — a divine punishment - points to her resigned acceptance of the impossibility of earthly retribution.

Under such circumstances, perpetrators become crucial witnesses to their own crime. This reliance is at once practical and loaded, as filmmaker Eyal Sivan has observed: "The primary witness of any war crime is the perpetrator himself or herself. Perpetrators' testimonies reveal the actions they committed, and the reasons they provided — or still provide — as a vindication of their criminal behavior." 14

And yet, allowing this voice to reign, once again, over the narrative that has silenced so many through physical and virtual violence is discomfiting at best. 
Nothing new to the field of genocide studies, perpetrator testimony and documentation have played a crucial role in historiography, particularly when victims' trauma might cultivate misrepresentation or misremembering that would cast the entire event into doubt. Yet here too questions of reliability arise, such as in the defensive evasions and self-serving imaginations depicted in The Act of Killing.

Silence shows how impunity has left the killers shockingly boastful, whether in the gruesomely detailed description of a sliced breast or in the multiple recollections of drinking blood — an ingestion of fluid intended to stave off madness. The casual mien with which many detail the horrors is disquieting, both in terms of an acceptance of their acts and a general absence of conscience, butan underlying anxiety is revealed in angry outbursts, when family members protest the possibility of complicity or where the interviewees deflect accountability or make threats. With his face twitching throughout the interview like the bustling larvae of the opening scene, Amir Siahaan, former leader of a Konando Aksi death squad, acknowledges his role but then denies complicity, gesturing to those higher in command. When Adi persists, Siahaan warns him that his work could be seen as subversive communist activity. My Busrun, one-time secretary general of Komando Aksi and current holder of a seat in the governmentlegislature, goes further, chiding Adi for making an issue of the past, and hinting that if he persists, history will surely repeat itself.

Such encounters highlight the additional challenges of collecting testimony. Beyond the danger inherent in the process, there is the question of eliciting trustworthy accounts. Much like documentary, testimony is intended to be a truthful recounting of the past, but like documentary, it is subject to both rhetorical and cinematic filters necessary in cultivating understanding and affect-as well as to the vagaries and varying credibility of its subjects. 
The film's most striking image, that of an interview subject wearing the phoropter for the eye-examination component of the exchange, expresses this dynamic. This device, prominent in Adi's interviews, offers a generative metaphor for the film's explorations. The combination of eye exams and interviews suggests a double effort by Adi and Oppenheimer to gain clarity and combat the myopia and occlusions that beset historiography as well as physiology.

This mechanism hints at Dziga Vertov's "kino eye” which surpasses human flaws and claims mastery over what it sees. As such, this device would sền to promise a resolution of conflict and clarity. Yet the reliance on the witness challenges this indifferent and objective as reminders of the deeply subjective nature of testimony and documentary come to the fore. "Which-is better? This one, or this one?" the optometrist asks in the task of setting vision aright. Each filter, whether lens, query, or subject perspective, affects the choices and the expression. This machinery is not the sole mechanismforproducing legibility of the past; there is no technology for visualization free from human elements of self-interest or selfpreservation. The reluctance of the perpetrators to fully participate draws attention to this hybrid property of testimony, one that unites evidence and narrative, the objective and the subjective

At the same time, many sequences reinforce the significance of the camera's witnessing function, especially when the interviewees look beyond Adi and the camera to address Oppenheimer. In such moments, the seeming transparency of the observational gaze is disrupted, in a move that might be a gesture to reflexivity and acknowledgment of the wider context of production, or instead might align Oppenheimer and Adi with the technologies and format of transparency. This minor shift, which occurs intermittently throughout the film allows for the contemplation of 
testimony's truth value at the same time it hails the documentary's claims on its narrative of a past in which a genocidal purge took place, and was subsequently, and paradoxically, veiled and justified.

Claims to transparency are simultaneously posited and withdrawn throughout the documentary. This persistent oscillation introduces, intentionally or not, the veracity gap that points up the contradictions besetting such attempts to bear witness to the past and the efforts necessary to close the distance between the event that took place and its articulation. The event cannot be seamlessly recalled or reptayed, even when the formal use of observation suggests immediacy or even indifference; rather, an amalgamation of factors is necessary, with the process andits outcome always fraught. This strategy could be seen to secure Oppenhermer's credibility through what Paul Arthur described as an "aesthetics of failure," whereby "failure to adequately represent the person, event, or social situation stated as the film's explicit task functions as an inverted guarantee of authenticity." "However, the attention to the persistent challenges seems to imvite consideration rather than to feign closure of the veracity gap.

Adi's participation contributes to this zone of irresolution: He is an optometrist whogiłes eye exams. This is a genuine offer made in exchange for the interviews. And yet, this is equally work performed over and over, in service to his quest for confession, recognition, and remorse. As in the case of its more grandiose predecessor, Silence allows the pretense to lead into the truth of the matter. Silence gives voice to denial, the suppression of this past, and the impact on survivors. It inhabits and confronts the veracity chasm opened by willful political amnesia, a chasm in which the survivors live. 
Not only does Adi collect testimony through his interviews, he also watches many videos already collected by Oppenheimer in which men describe their actions. In one video, there is a tour of the river by Ramli's murderers. Reenactment is kept to a minimal register as they walk through the reeds, talk, and occasionally gesture for emphasis. Their matter-of-fact and quite detailed description as they tour the site gives a sobriety and shameless credibility to their interview.

A sole piece of archival news footage is even more shocking. This item from the time of the coup features a journalist interviewing one of the killers, who insists that the communists wanted to be murdered; the reporter leaves this claim unchallenged. The use of news footage as expository device iscommon to most documentaries for its presumed record of history and implicit authority (even when subject to testing and troubling). Although the archival footage stands at a remove from the live report, it still carries the aura of the artifact and of the original witness. Even as an interview, the clip suggests "presence at a distance," an ability to see history before the onslaught of historiography, even as it is already folded into the latter. $^{16}$

In this case, though, its history already gestures to the self-serving historiography of the perpetrators. The footage is the true record of a lie (the communists wished to be killed) as well as of a truth (they were killing communists, among others). Moreover, it calls into question the transformative expectations that attend the act of testimony and documentary exposure of injustice - that if people see something, they will do something, to put it coarsely. ${ }^{17}$ By disrupting the belief that knowledge leads to action, such moments call attention to revelations of genocide on the world stage that nonetheless resulted in international silence. 
The motif of the mediated encounter continues this questioning as both films show spectators watching footage. In Killing, Anwar Congo's notorious act of retching is precipitated by the playback of an assassination sequence. The sequence embraces cathartic assumptions of viewing, suggesting that both reenactment of the past and the watching of the past enable verbal and purgative release. In effect, the act suggests the transformative power of viewing testimony in any of its guises (dramatic reenactment or first-person recollection).

By contrast, when Adi watches the footage of perpetrator testimony collected by Oppenheimer, he is silent and maintains an impassive expression, emphasizing impenetrability and uncertainty, if not between Adi and the perpetrators, then between the audience and Adi, whose face becomes a screen for another set of projections. He could be disappointed by or dismayed with the lack of confession. He might be puzzled. His response is unknown, no matter how long the camera lingers.

Where Killing performs and pantieipates in the illusion of testimonial transparency and its immediate efficacy, Silence confounds any such expectation. It substitutes the sober strategies of audiovisual testimony and observational photography, tactics that have a presumably greater link to the real, to reveal the challenges in witnessing the collected testimony. Adi watches the men give calm descriptions of torture and murder that simultaneously defy belief and appear credible, possibly for their lack of apparent passion. Yet even with this knowledge, nothing has yet changed. Inevitably, straightforward comprehensibility and instantaneous change are fictions; frustrations instead characterize the victims' reality and historiography.

Despite these injections of doubt, bolstered through the sober footage, Silence does not dispense with the promise of testimony. In one sequence, Adi visits with a man rendered senile in his old age and cared for by his daughter, whose voice is 
initially heard in the establishing shot outside the house as she expresses pride in her father's killing of communists. Inside, the father describes bringing a woman's head to a coffee shop in order to terrorize the Chinese there, and provides the grisly detail of draining and drinking the blood so as to preserve his sanity. His daughter's response is conflicted, clearly sickened by his sadism yet conceding that the blood may have maintained the physical strength he shows in the present.

Adi's reference to Ramli yields only silence and the defensive phrase "it's getting late" from the father. Statements of past violence are offered, but without an acknowledgment of political responsibility. There is no confession Amid these already divergent responses, comes another, as the daughter reaches out to Adi to apologize even as she defends herself as being too young then to have understood what was happening. She extends a form of appeasement, offering her and her father as family. They must come together, she insists. The scene becomes a microperformance of truth and reconciliation, both fraught. There is no full confession from this senile, elderly man and the amends of family building might be a gesture to move on from the past rather than any guarantee of restorative justice processes. By placing this sequence well in advance of the film's conclusion, Oppenheimer uses his narrative structure to further impede any assumption of triumphant transformative potential.

Adi's visit with the family of Amir Hasan, one of his brother's killers, leads to even more frustrating and frustrated results. Adi has brought a book, produced by Hasan himself, that provides a horrific and illustrated chronicle of the torture and murder of Ramli. But Hasan, also responsible for the deaths of at least thirty-two other villagers, has since passed. His death leaves only his wife and two sons to interview. Ironically, despite their earlier three-month collaboration with 
Oppenheimer to adapt the book, the family's denial is fierce. ${ }^{18}$ The widow refuses to acknowledge that it is her husband's book and the two sons declare themselves too young to have known anything. One of the young men balks and makes the darkly comic suggestion that they all just try to get along, like the military dictatorship taught them. Oppenheimer's footage of Hasan is screened for them, but rather than cause the family to recant its denial, or even to open the conversation (as was the aim), it provokes the widow into threatening to leave and warning Joshua, sitting offscreen, not to make trouble.

As the final interview prior to Adi's return home, this scenc performs the opposite of Congo's retching in Killing. There is neither a verbatnor somatic outpouring of truth nor any purging of guilt. Despite Adi's wish for a replication of the Gacaca tribunals, the form of traditional justice adtapted in Rwanda in the aftermath of the genocide to make truth public and to reconcile with one's neighbor, any such process in Indonesia is still far off. ${ }^{19}$ Rather, this transitional justice is itself still in transition, bound by the past and its gatekeepers, still awaiting its moment.

The shots that conclude The Look of Silence express the ongoing burden of the past and the liminalstate' of the nation. First is a shot of Adi's father, scurrying and panicked, uncertain of where (or when) he is, yet tormented by a nameless fear. The return of the repressed extends beyond the psychic and the screen: Adi himself shot this footage of his father prior to or during the production of The Act of Killing with a camera he received from Oppenheimer in 2010 in order to record evocative visuals for the film to come. ${ }^{20}$ The absence of onscreen date or source information could be seen as deceptive, eroding the evidentiary value that the observational footage otherwise conveys, yet it equally speaks to the temporal entanglements brought about by trauma which respects no chronology in its comings and goings. 
Past, present, and future are invoked in the scene at the close of the film when Adi's mother addresses a mass of twitching larvae, which also appeared in the opening titles. These trembling pods are evocative, natural items buffeted by an unseen force, much like the survivors by their traumatic past or the lies of the perpetrators in the present. And they are burgeoning with a life in development, one to come. "I can't see you, but you are there," she tells these creatures in transition, present but not fully present, inchoate, still waiting to become fully manifest.

Oppenheimer's interrogations of the mechanisms of testimony paradoxically ensure the film's transformational deployment. The Look of Silenee, with its accumulation and remediation of testimonies, has been mobilized in the quest for justice. Markedly different from The Act of Killing, which called attention to the murderous fantasies that governed historical memory, Silence returns to the approved model of documentary testimony for genocide. Following the path of Shoah (Claude Lanzmann, 1985), it focuses on the present and the interview, signaling the simultaneous impossibility and necessity of bearing witness to genocide, particularly in the mobilization of political justice. Even Adi's mission to capture expressions of recognition and remorse opens a space, however provisional, for future action by a future recipientof these cinematic testimonies. With assistance, the willingness to speak of the past can be cultivated, and put to use not as an instrument of fear, but as a component of truth and reconciliation.

Already, the discourse and activity around Silence support Adi's aim, one about which Oppenheimer has been explicit: "Hopefully the film will be a tool for other human rights activists and lend moral authority to the argument that something needs to be done, and will make the demand more compelling." He stated this intent 
in an interview shortly after the film's US debut, adding his wish that the incoming Indonesian president would also eventually watch the film. ${ }^{21}$

After the Jakarta Arts Council and the National Human Rights Commission (Komnas HAM) hosted the Indonesian premiere of the film in November 2014 for an audience of 1,500, an editorial in the Jakarta Globe praised it, writing that Silence "should serve as the first of many public screenings for similar movies that attempt to debunk the lies ... [and that] President Joko Widodo should take note of people's support and rightful interest in this film and read it as demand for a leadên of his stature to enable Indonesia to confront its past.",22 This wish was in part fulfilled as numerous community screenings were held in the month that followed, including 130 that were open to the public on International Human Rights Day (December 10, 2014). ${ }^{23}$ Amnesty International UK, promoting the film on its blog, includes information from Indonesia's Human Rights Commission, a link to their own report, and a pdf file including details about the film, the 1965 coup, actions one can take, and contact information (including President Widodo's twitter address). ${ }^{24}$

The repeated reference to President Joko Widodo is not simply political expedience. In July 2014, he won the election as the candidate from the center left Indonesian Depocratic Party of Struggle. Emerging from an underprivileged background to become initially mayor of Surakarta and then governor of Jakarta, he is the first president from outside the ruling party or military elite. This democratic election of an "outsider" and known reformer was often held as evidence of progress and possibility although his insistence on the death penalty (including for foreign nationals) and his reluctance to pursue an investigation of the December 2014 Paniai massacre in West Papua have ushered in considerable doubt. ${ }^{25}$ Nevertheless, the new president's rise to power along with numerous local screenings of Silence may prove 
fruitful, particularly if a more robust grassroots network develops to implement the film and the collection of video testimonies in projects to confront and address this past.

Although Oppenheimer is not participating in the activist plans for the film, he has expressed the belief that this documentary, along with the recorded testimonies, confers "moral authority" on these endeavors. This intended authority, [even if tenuous, helps to explain the shift in filming and his turn from the ontologically and epistemologically challenging tactics of its predecessor. Even so, Silencê suggests that the much-needed instrument of justice — documentary testimony $<$ today faces profound challenges in a context of impunity and complicity. Refusing dogmatic exposition, the film contains a hesitation or gap, allowing the struggles of mediation to become visible, even if for only a glimpse. Its sober footage is inflected by uncertainty, by an oscillation between acknowledgment and denial, with survivors captured in between. This tension expresses the conditions of those living within the dangerous fantasy world of former perpetrators where justice has yet to arrive. The act of collecting testimony is laden with physical risk, and the testimony, provided by the murderers, is fraught, simultaneously truthful and suspect.

But the restrained style suits, providing a clear head and authoritative vision to counter the fantasies that dictate the perpetrator's world. In all its gestures and explorations into the frustrations and challenges of testimony, whether practical or traumatically induced, Silence returns its audience to the necessity of sober documentary expression, if a film is truly to implement change and render palpable a reigning testimony of silence that continues to inhibit its implementation. 
Editor's note: For in-depth analysis of Joshua Oppenheimer's The Act of Killing, see the special dossier in Film Quarterly (in 67.2, Winter 2014, 8-56) with essays by Warren Crichlow, Nick Fraser, Homay King, Bill Nichols, Intan Paramaditha, Brad Simpson, and Janet Walker, and an interview with Oppenheimer by Irene Lusztig. ${ }^{1}$ I am immensely grateful to B. Ruby Rich for her helpful feedback on this piece.

${ }^{2}$ Joshua Oppenheimer, as cited in Patricia Aufderheide, "Josh Oppenheimer Wants to Reinvent the Human Rights Film," Center for Media and Social Impact blog, March 5, 2015, www.cmsimpact.org/blog/media-impact/josh-oppenheimer-wants-reinventhuman-rights-film.

${ }^{3}$ Miriam Bratu Hansen discusses this paradigm in "Schindter's List is NOT Shoah," in Spielberg's Holocaust: Critical Perspectives on Schindler's List, ed. Yosefa Loshitsky (Bloomington and Indianapolis: Indana University Press, 1997), 77-103. ${ }^{4}$ Hayden White, "The Modernist Event" The The Persistence of History: Cinema, Television, and the Modern Event, ed. Vivian Sobchack (New York and London: Routledge, 1995), 31.

${ }^{5}$ See, for instance, BillNichols, "Irony, Cruelty, Evil (and a wink) in The Act of Killing," Film Quarterly 67.2 (Winter 2013) and Janet Walker, "Referred Pain: The Act of Killing and the Production of a Crime Scene," Film Quarterly 67.2 (Winter 2013): 14 .

${ }^{6}$ Nick Fraser, "We Love Impunity: The Case of The Act of Killing," Film Quarterly 67.2 (Winter 2013): 22.

${ }^{7}$ Joshua Oppenheimer, "Production Notes," The Look of Silence, http://thelookofsilence.com/ (last accessed May 15, 2015).

${ }^{8}$ The Globalisation Tapes is available for viewing on YouTube at www.youtube.com/watch?v=Xo2OOIMkYOE. 
${ }^{9}$ Cited in Sean O’Hagan, “Joshua Oppenheimer: Why I Returned to Indonesia’s Killing Fields," The Guardian, June 7, 2015, www.theguardian.com/film/2015/jun/07/joshua-oppenheimer-the-look-of-silenceinterview-indonesia.

${ }^{10}$ John Durham Peters, "Witnessing," in Media Witnessing: Testimony in the Age of Mass Communication, ed. Paul Frosh and Amit Pinchevsky (Hampshire, UK and New York: Palgrave MacMillan, 2009), 23-41.

${ }^{11}$ Karen Attwood, “Adi Rukun Interview: The Subject of a Haunting New Documentary on Meeting His Brother's Killers," Independent, Jane13, 2015, www.independent.co.uk/arts-entertainment/films/features/adi-rukun-interview-thesubject-of-a-haunting-new-documentary-on-meeting-hisłbrothers-killers10318189.html.

${ }^{12}$ Janet Walker, “The Traumatic Paradox:Prcumentary Films, Historical Fictions, and Cataclysmic Past Events," Signts 22.4 (Summer 1997): 803-25.

${ }^{13}$ See, for instance, Cathy Caruth, Unclaimed Experience (Baltimore, MD: Johns Hopkins University Preșs,1996); Shoshana Felman and Dori Laub, Testimony: Crises of Witnessing in Literature, Psychoanalysis and History (New York and London: Routledge, 1992); Walker, "Traumatic Paradox." ${ }^{14}$ Eyal Sivan, "Common Archive Palestine 1948: Web Archive \& Production Platform [in progress]," Eyalsivan.info, http://eyalsivan.info/index.php?p=elements1\&id=6\#\&panel1-8.

${ }^{15}$ Paul Arthur, "Jargons of Authenticity (Three American Moments)," in Theorizing Documentary, ed. Michael Renov (New York: Routledge, 1993), 127.

${ }^{16}$ This idea draws upon but does not map out John Durham Peters's discussion of liveness and the media event. 
${ }^{17}$ I discuss these assumptions in Creating the Witness: Documenting Genocide on Film, Video, and the Internet (Minneapolis and London: University of Minnesota Press, 2012), 1-2.

${ }^{18}$ Jess Melvin, "Interview: Oppenheimer on The Look of Silence," IPT1965, May 27, 2015, http://1965tribunal.org/interview-oppenheimer-on-the-look-of-silence/.

${ }^{19}$ Attwood, “Adi Rukun Interview."

${ }^{20}$ O’Hagan, “Joshua Oppenheimer.”

${ }^{21}$ Oppenheimer, as cited in Samuel Oakford, “'Indonesia Is Clearly in a Transition': VICE News Talks to Joshua Oppenheimer, Director of The Act of Killing and The Look of Silence," Vice News October 28, 2014, https://news.vice.com/article/indonesia-is-clearly-in-a-transition-vice-news-talks-tojoshua-oppenheimer-director-of-the-act-of-killing-and-the-look-of-silence.

${ }^{22}$ Anon., "Editorial” Leadership to Look at Past Long Overdue," Jakarta Globe, November 13, 2014, http://thejakartagløbe.beritasatu.com/opinion/editorialleadership-look-at-past-long-@verdue/.

${ }^{23}$ Dean Irvine, "The Look $\circ$ f Silence: The Film Making Indonesia Face Its Brutal History," CNN.com, November 14, 2014, http://edition.cnn.com/2014/11/13/world/asia/indonesia-the-look-of-silence/; Anon., "The Look of Silence in Indonesia on Human Rights Day," Danish Film Institute, December 11, 2014, www.dfi.dk/Service/English/News-andpublications/News/December-2014/The-Look-of-Silence-in-Indonesia.aspx; Attwood, “Adi Rukun Interview.”

${ }^{24}$ Anon., "If You Do One Thing on 14 June Go to See The Look of Silence," Into the ether, Amnesty International UK blog, May 27, 2015, 
www.amnesty.org.uk/blogs/ether/if-you-do-one-thing-14-june-go-see-look-

silence\#justice.

${ }^{25}$ See, for instance: Agence France Presse, “Joko Widodo Appoints Indonesia’s First Female Foreign Minister, Retno Marsudi,” The Guardian, October 26, 2014, www.theguardian.com/world/2014/oct/27/joko-widodo-appoints-indonesias-firstfemale-foreign-minister-retno-marsudi; David Pilling and Ben Bland, "Indonesia: No More Mr Nice Guy," Financial Times, May 3, 2015, www.ft.com/cms/s/0/5685edbaeda2-11e4-987e-00144feab7de.html\#axzz3g3NgJCVI; Duncan Roden, "West Papua: Video Shows Aftermath of Indonesia's Paniai Massacre," Green Left Weekly, April 17, 2015, www.greenleft.org.au/node/58769. 